\title{
IJBF CROSS-BORDER MERGERS AND ACQUISITIONS BETWEEN INDUSTRIALIZED AND DEVELOPING COUNTRIES: US AND INDIAN MERGER ACTIVITY
}

\author{
Gordon V. Karels, Edward Lawrence and Jin Yu \\ University of Nebraska-Lincoln, \\ Florida International University and \\ St. Cloud State University, US
}

\begin{abstract}
In this paper we study the cross border mergers and acquisition between the US. and Indian firms. Our empirical work suggests that US firms realize significant losses on the announcement of acquisitions of Indian targets while Indian targets realize significant gains on the announcement of mergers with US acquirers. Publicly-traded Indian firms realize insignificant returns on their announcement of acquisitions of publicly-traded US firms but realize significant positive returns on announcements of acquisitions of privately-held US firms and subsidiary firm targets. Publicly-traded US targets realize insignificant gains when US acquired by Indian firms.
\end{abstract}

Keywords: Cross border mergers and acquisitions, Acquirer's abnormal returns, Target's abnormal returns, Publicly traded acquirers, Privately held targets

JEL Classification: G34, G14

\section{Introduction}

Much of the current research on cross-border mergers focuses on analyzing the returns of industrialized firm's acquisitions of emerging world targets. ${ }^{1}$ Little attention has been given to acquisitions of developed country targets by emerging world country firms. Also, researchers have focused primarily on the returns to the acquirers and none of the studies to date have investigated the effect of announcement of mergers and acquisitions on the target firms in the cross border

\footnotetext{
1 We use "emerging" and "developing" interchangeably and "industrialized" and "developed" interchangeably throughout the paper.
} 
mergers and acquisitions involving developed and developing world firms. We study both types of cross-border merger activities by examining the Indian and US company returns when US firms are acquirers of Indian firms and when Indian firms are acquirers of US firms. ${ }^{2}$ We find that there is no country effect when a publicly-traded firm acquires a publicly-traded target or subsidiary firm target but there is a significant country effect for public-traded acquirers of privately-held targets US (acquirers earn significantly lower returns than Indian acquirers). Our investigation for the target firms reveals that acquisition by any US firm (public, private or subsidiary firm) is beneficial to the shareholders of the Indian targets whereas the US public targets earn insignificant returns on the announcement of their acquisition by Indian firms. We also find that the abnormal returns for the targets of publicly-traded acquirers are consistently higher than the abnormal returns of targets of privately-held acquirers.

Figure 1 shows the dramatic increase over the last few years in mergers and acquisitions between the US and Indian companies. Prior to 1995 there were few cross-border mergers and acquisitions between the US and Indian firms. Post 1995, US acquisitions of Indian targets reached more than 100 firms in 2000, then declined rapidly following the dot.com bubble burst. By 2006, US acquisitions of Indian targets were again close to 100 firms. Indian acquisitions of US firms followed a similar pattern with increases up to the year 2000 (but only about 50 transactions), then a decline following the dot.com bubble burst. By 2006, the number of transactions had risen above the year 2000 level. In Figure 2, we separate the cross-border mergers and acquisitions by types of ownership structure - publicly-traded, privately-held or non-traded subsidiary. The figure shows that Indian acquirers of US firms are largely publicly-traded firms whereas the US targets are typically privately-held firms. Mergers and acquisitions between US acquirers and Indian targets are spread across the publicly-traded, privately-held and subsidiary firms for both acquirers and targets.

Conn, Cosh, Guest and Hughes (2005) assert that there are important theoretical reasons why the acquisition of domestic and cross-border targets may differ and why acquisition of private targets may differ from the acquisition of public targets. ${ }^{3}$

\footnotetext{
${ }^{2}$ The economic environment and the business environment of countries play a crucial role in the decision to acquire or being acquired in cross-border merger and acquisitions (La Porta, Lopez, Shleifer \& Vishny, 1998, 1999, 2000). We cannot get meaningful information by studying all the developed world and the developing world countries together. Doing the merger and acquisition study for all the developing world countries separately in one paper would make the paper too voluminous. Hence we limit the scope of this paper to mergers and acquisitions in India and between India and the US and leave the mergers and acquisition in the remaining developing countries as a topic for future research.

${ }^{3}$ We refrain from the discussion as to why cross border mergers and acquisitions and why acquisition of private targets is different from the acquisition of public firms. Those issues are discussed at length in section 2 of Conn et al. (2005).
} 


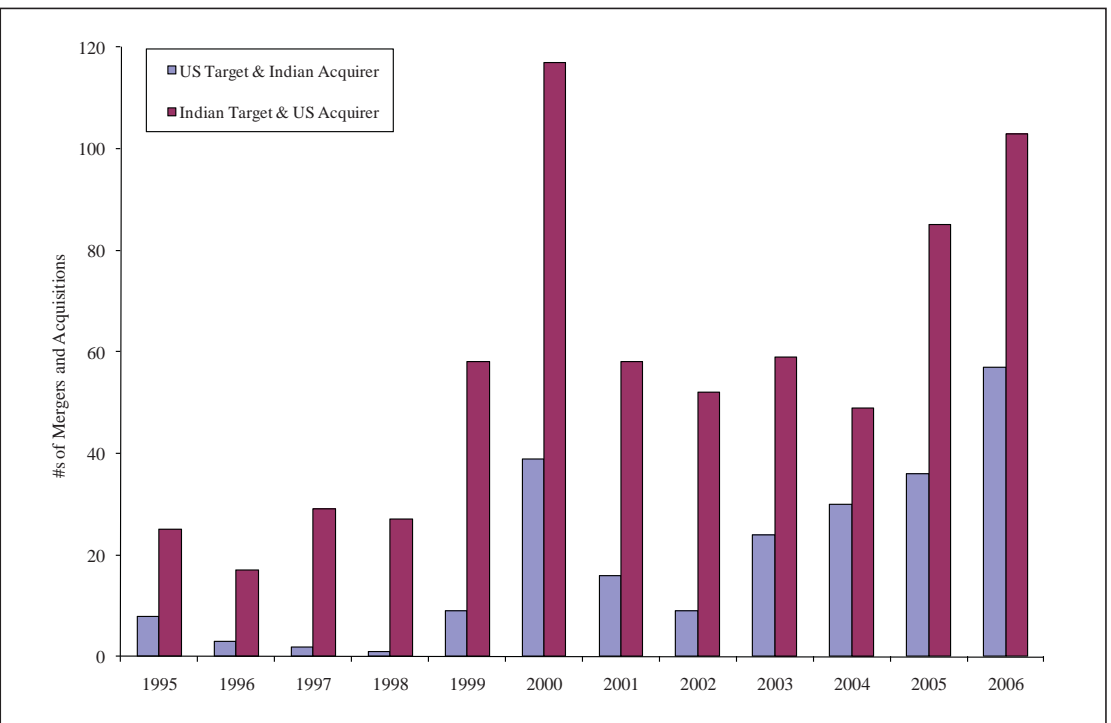

Figure 1: Number of mergers and acquisitions, 1995 to 2006

Source: SDC Mergers and Acquisitions Database

Figure 1 shows an increasing trend in the number of mergers and acquisitions between U.S. and Indian firms. Accordingly, we examine mergers and acquisitions between the US and Indian firms by separating them into different pairings: publicly-traded acquirers and publicly-traded targets, publicly-traded acquirers and privately-held targets, publicly-traded acquirers and subsidiary firms, privately-held acquirers and publicly-traded targets and subsidiary firm acquirers and publicly-traded target firms.

In the following figure we categorize the mergers and acquisitions by publicly-traded firms, by privately-held firms, by subsidiaries of large firms and by others (government firms, joint ventures etc.). Indian acquirers of U.S. firms are largely public and private firms but the U.S. targets are largely privately held and subsidiaries of large firms. Mergers between the U.S. acquirers and Indian targets are spread across publicly-traded, privately-held and subsidiary firms for both acquirers and targets.

There is substantial literature on the announcement effects of crossborder acquisitions on acquiring firms in developed countries such as the US and the UK but there is limited work that has been done examining mergers and acquisition between the acquirers and the targets of a developing country (such as India) and an industrialized country (such as the US). In cross-border mergers and acquisition studies involving acquirers, Moeller and Schlingemann (2005) have one target Indian firm; Francis, Hasan and Sun (2008) have 13 target Indian firms; and Chari, Ouimet and Tesar (2010) have 33 target Indian firms in their samples. Using a comprehensive sample of 248 firms, in this paper we study the announcement effect of mergers and acquisitions on the acquirers of Indian 
targets. Also, none of the studies done to date have studied the announcement effect of mergers and acquisitions on the target shareholders of the firms from the developing world. Conn et al. (2005) stated that despite the increase in the acquisition of cross-border public and non-public targets, nearly all acquisition studies were limited to domestic targets which were publicly traded. They studied the acquisitions of both domestic and cross-border targets that were public and private but they limited their study to the effect of acquisition on UK acquirers only. Utilizing merger and acquisition data from 1995 to 2007 we address the announcement effect on publicly-traded acquirers of publicly-traded, privatelyheld and subsidiary targets, and on publicly-traded targets by privately-held firms for US acquirers and Indian targets and Indian acquirers of US targets.

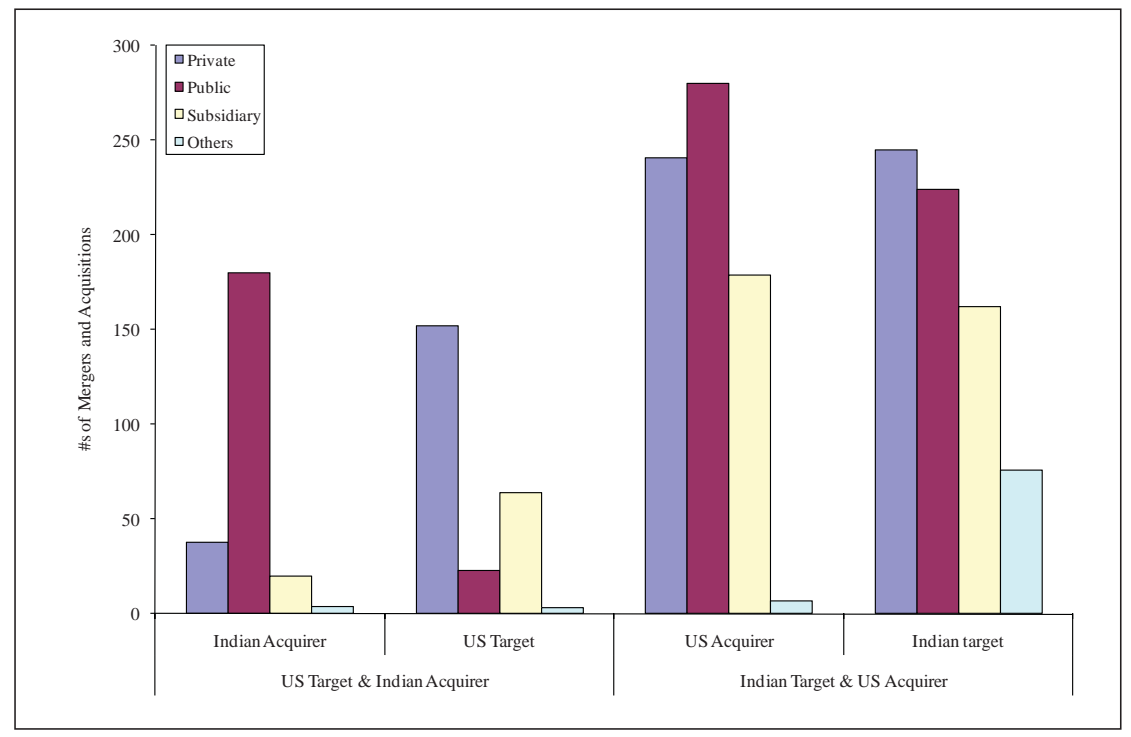

Figure 2: Types of mergers and acquisitions

Source. SDC Mergers and Acquisitions Database

We find that Indian target firms when acquired by a publicly-traded US firm, realize positive abnormal returns around the announcement date whereas acquiring firms suffer a loss of market value around the announcement date. Indian targets acquired by privately-held US firms enjoy significant gains on the announcement of a merger or acquisition. In the case of an Indian acquisition of a US target, the acquiring Indian firm experiences positive abnormal returns around the announcement date. The returns to an Indian acquirer of a publiclytraded US firm are statistically insignificant whereas Indian acquirers realize significant abnormal returns around the announcement date of the acquisition of privately-held US firms and the subsidiaries of US firms. US targets realize statistically insignificant returns on the announcement of a merger or acquisition by Indian firms. 
Our results indicate that the shareholders of Indian acquirers of privatelyheld US targets and US subsidiary firm targets gain from the announcement of an acquisition whereas the share prices of US acquirers of privately-held Indian targets fall on the announcement of an acquisition. ${ }^{4} \mathrm{We}$ investigated if this difference in cross-border mergers and acquisitions was due to firm characteristics or was due to the country environment. We examined the firm characteristics of the acquirers and found that Indian and the US acquirers of privately-held targets have similar high tech status and similar diversification levels. Indian acquirers of US subsidiary targets have substantially greater high tech status and higher diversification levels than the US acquirers of Indian subsidiary targets. For all target categories, the relative size of targets is substantially smaller for US acquisitions. The market value of Indian acquirers is also significantly lower than the market value of US acquirers. Both Indian and US firms, acquire majority stakes in target firms but the average stake acquired is higher in private and subsidiary firm targets than in publicly-traded targets.

To determine if the reaction to the news of an acquisition is due to firm specific characteristics, we regressed the three-day cumulative abnormal return around announcement ( -1 day to +1 day after announcement) on firm specific characteristics and a dummy variable identifying the country of the acquirer. Our results indicate that there is no influence of the country environment when a publicly-traded firm acquires a publicly- traded target or subsidiary firm target as the dummy variable for the country remains insignificant. The dummy variable is significant for public-traded acquirers of privately- held targets indicating that the US acquirers earn significantly lower returns than Indian acquirers.

Our results differ from the recent research of Chari, Ouimet and Tesar (2010) and Gubbi, Aulakh, Ray, Sarkar and Chittor (2010). Chari et al. (2010) studied the returns to the developed market acquirers of emerging market firms. They reported a positive and significant abnormal return for the developed country acquirer of targets from emerging markets whereas we found a negative but insignificant abnormal return for the US acquirers of Indian targets. They found that private targets were associated with significantly higher announcement returns for acquirers from developed world countries whereas we found that US acquirers of private Indian targets earned significantly negative abnormal returns.

Gubbi et al. (2010) found that the Indian acquirers of foreign targets (both developing and developed country firms) gained on the announcement of their mergers and acquisitions. However, when they regressed the abnormal returns on explanatory variables, the coefficient on private targets was positive and insignificant in one model (as in their Table 4) and negative and insignificant in the other (in Table 5). We found that Indian acquirers of targets earned significant, positive abnormal returns on the announcement of US acquisitions of targets but this gain was limited to the acquisition of private targets only.

\footnotetext{
${ }^{4}$ Our results are consistent with the findings of Moeller and Schlingemann (2005) and Denis, Denis and Yost (2002), who find that cross-border M\&As for acquirers decrease acquirers' value. Our results do not support the findings of Chari et al. (2010), Francis, Hasan and Sun (2008), Kiymaz (2004), Doukas (1995), and Doukas and Travlos (1988), who find that cross-border M\&As are value enhancing for acquirers.
} 
The size of our sample allows us to avoid the grouping of targets and acquirers from different countries. Whereas, the developed world countries are somewhat economically and culturally similar to each other there are large differences across the countries of emerging markets. Studying cross-border mergers and acquisitions between representative developing and industrialized countries should provide less noisy information.

The rest of the paper is organized as follows: Section 2 reviews related literature and section 3 discusses the data sources and methodology. Section 4 presents the empirical results. Section 5 provides some of the probable cases for the gains/losses of the shareholders of the acquirers and the targets, and section 6 concludes.

\section{Literature Review}

We summarize the literature on cross-border mergers and acquisitions in Table 1; US targets gain significantly when acquired by foreign firms, foreign acquirers of US firms gain significantly whereas the US acquirers of foreign firms show mixed results. The firms in these studies are predominantly from industrialized countries.

Markides and Ittner (1994) examined 276 U.S. international acquisitions made from 1975 to 1988 and found the two-day cumulative abnormal return [CAR $(-1,0)]$ for acquiring firms to be $0.32 \%$ (statistically significant). Most of the acquisitions in Markides and Ittner's study came from the manufacturing and finance, and insurance industries and are from predominantly developed countries.

Markides and Oyon (1998) used a sample of 236 US acquisitions consisting of 47 Canadian targets and 189 European targets (32 from France, 81 from UK, 27 from Germany, 13 from Italy, 14 from Spain, 15 from Holland and 7 from Belgium) and found that US acquisitions in Europe generated significant returns while returns for US acquisitions in UK and Canada were not significant.

Seth, Song and Pettit (2002) investigated 100 cross-border acquisitions between foreign acquirers and US targets during the time period 1981-1990. They found that the cumulative abnormal return [CAR $(-10,10)]: 10$ days before and 10 days after the first bid by the ultimately successful bidders) to the foreign bidder was 0.11 per cent. ${ }^{5}$ The acquirers of the 100 cross-border acquisitions in this study were mainly from industrialized countries - Great Britain (52), Japan (10), Canada (10), Australia (8), West Germany (3), and Switzerland (2).

Conn et al. (2005) studied 4,000 UK domestic and cross-border public and private acquisitions. For the acquirers of publicly traded targets they found significant losses for domestic mergers and acquisitions but insignificant losses for cross-border mergers and acquisitions. They found significant gains for acquirers of privately-held firms for both domestic and cross-border targets.

${ }^{5}$ Seth et al. (2002) did not study the returns for the targets. Also, the statistical significance of the CAR is not reported in their paper. 
Karels et al.: Cross-Border Mergers and Acquisitions

Cross-Border Mergers and Acquisitions between Industrialized and Developing Countries: 35-58

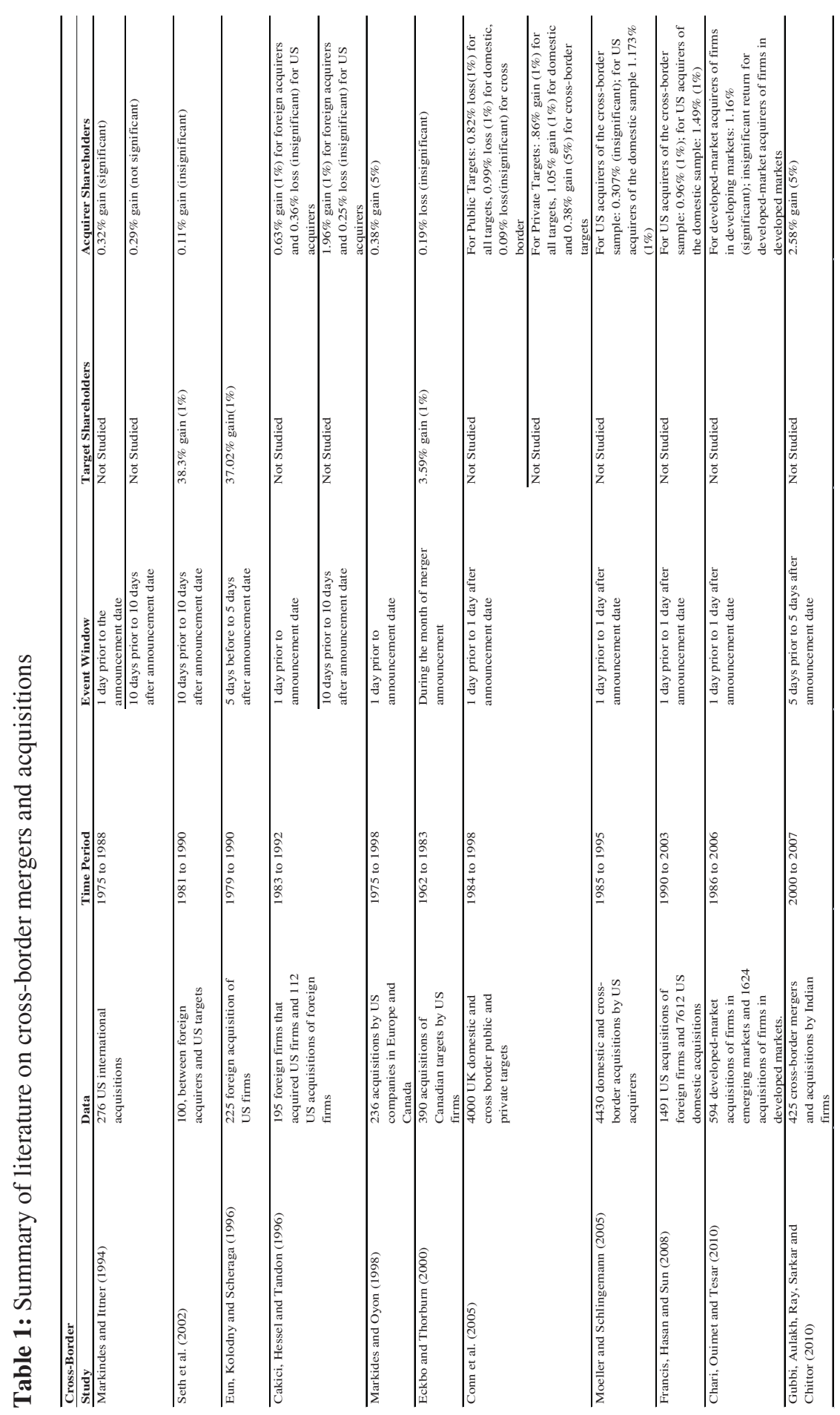


Moeller and Schlingemann (2005) studied the announcement effect on US acquirers for a sample of 383 cross-border transactions and 4047 domestic takeover transactions during 1985 to 1995 . They found a three-day $(-1,+1)$ market adjusted return of 0.307 per cent for cross-border acquirers and 1.173 per cent for domestic acquirers. In the Moeller and Schlingemann (2005) study, the UK is the most frequent target country (31\%), followed by Canada $(21 \%)$, France $(9 \%)$ and Germany $(9 \%)$. In their sample there is only one target firm from India.

In a recent study, Francis, Hasan and Sun (2008) used a sample of 1,491 foreign acquisitions by US firms and 7,692 US domestic acquisitions. They found that over the full sample period of 1990-2003, acquirers in domestic M\&As experienced an average abnormal stock return of 1.49 per cent whereas the acquirers in cross-border M\&As experienced an average abnormal return of $0.96 \%$. Among their 1,491 transactions, 1,275 (85.50\%) were from integrated financial markets, with the remaining 215 (14.50\%) from segmented financial markets. There were only 13 Indian firms acquired by US firms in this sample.

Most merger and acquisition studies have focused on publicly-traded firms within the domestic US market or those between the US and other industrialized countries. Little research has examined the returns to shareholders from crossborder mergers and acquisitions between the US and developing country firms. ${ }^{6}$ Chari, Ouimet and Tesar (2010) filled this gap and examined the returns to shareholders of developed country firms that undertook acquisitions in emerging markets. They found that when developed country acquirers gained control of emerging-market targets, they experienced positive and significant abnormal returns of 1.16 per cent, on average, over a three-day event window. Though Chari et al. (2010) studied the acquisition of targets from India by developed world firms there were only 33 target firms from India. In this paper we have a sample of 248 firms from the acquiring targets in India. Chari et al. (2010) did not study the effect of announcement of mergers and acquisitions on target firms. Also, they did not study the acquirers of targets from developed world firms (like US) by developing world firms (like India).

Research by Gubbi, Aulakh, Ray, Sarkar and Chittor (2010) studied 425 foreign mergers and acquisitions by Indian firms from January 2000 to December 2007. They found positive abnormal returns for the acquiring firm shareholders when combining all target firm countries (developing and emerging) into one group. They investigated if the abnormal returns for the acquirers of developed world targets were different than those for emerging world target and found that acquirers had statistically higher abnormal returns when the target firms were located in advanced economies. They also investigated if the returns for the acquirers of private targets were different from the returns for public targets but

${ }^{6}$ Francis, Hasan and Sun (2008) have only 14 per cent of their cross-border sample from developing countries and the Moeller and Schlingemann (2005) study has only 5.2 per cent of targets from developing countries. Rossi and Volpin (2004) examined the determinants of cross-board mergers and acquisitions from 1990 to 1999 with few of their target firms from developing countries. 
found no significant results. In their Table 4, they performed a cross-sectional regression on the abnormal return for the acquirers around announcement date and reported a negative and insignificant 'private' variable which was one for private targets and zero for public targets. In their Table 5, Gubbi et al. (2010) reported a positive an insignificant 'private' variable for a different cross sectional regression model. Hence their findings on the abnormal returns to the acquirers for different public/private stat were ambiguous. Also, Gubbi et al. (2010) did not study the announcement effect of mergers and acquisitions on the target firms.

Cross-border mergers and acquisitions can be beneficial for the acquirers resulting in positive abnormal returns on the announcement date; they can also result in losses for the acquirers. Researchers have given several reasons for the gains from cross-border mergers and acquisitions. Caves (1971, 1998), Morck and Yeung $(1991,1992)$ and Williamson (1979) point to the internalization benefits in the cross-border mergers and acquisitions. Firms extract above normal returns from cross-border investments by internalizing the host country market imperfections when their firm specific assets cannot find comparable values elsewhere. Ayban and Ficici (2009) note that the resulting rents derived from internalization are expected to be capitalized into a higher value of the firm. Baldwin and Caves (1991) point out that cross-border mergers and acquisitions may result in gains from diversifications when businesses seek synergies arising from intangible and information-based assets like brand names, technical knowledge and R\&D expertise. According to Kogut (1983) cross-border acquisitions may increase the operational flexibility of the firm by giving it the opportunity to exploit market conditions. Conn et al. (2005) state that in crossborder merger, geographical diversification by direct investments in overseas subsidiary permits firms to expand the boundary of the firm. This will result in an increase in revenues for the firm.

Researchers give several reasons for the loss from cross-border mergers and acquisitions. Conn et al. (2005) argue that overseas targets are more difficult to value accurately because of imperfect information. They point out that there are difficulties of managing the post-merger process when cultural differences make integration and acculturation, a difficult, time-consuming and expensive process. The bigger the cultural gap, the bigger the relative size of the target the worse the problem may be. Aybar and Ficici (2009) point out that differences in natural culture, customer preferences, business practices and institutional forces may jeopardize the potential gains of cross-border mergers and acquisitions. Hitt, Hoskissons and Ireland (2001), Hitt, Ireland, Camp and Sexton (2001) and Kissin and Herrera (1990) point out that complication in target assessments, misidentification of asset complementarities, informational asymmetries and high premiums paid for target may have adverse effects on the value of acquiring firms.

The above factors influence the developed and developing country firms differently. Furthermore, when a firm from a developed country acquires a developing country firm, it gains from the cheap labour thus reducing its 
operational cost whereas when a firm from a developing country acquires a developed world firm, it accesses the technological know-how thus increasing the growth potential for the firm. In their studies, Chari et al. (2010) have grouped countries into developed markets and emerging markets and Gubbi et al. (2010) have clubbed developed and developing world target countries together. Whereas, the developed world countries are economically and culturally similar to each other and can be grouped together, there exist noticeable differences across the countries of emerging markets. While the countries in the developed world are all democracies, there are different government structures in the emerging world countries. Whereas the countries in the developed world predominantly follow the same religion and have similar cultures, there are differences in the cultural and religious practices of the emerging world population. Whereas the judicial system in the developed world countries is strong, it is not so strong in all the emerging world countries.

The financial markets in all the developed world countries can be considered to be at least weak form efficient; the financial markets for many emerging world countries are not even weak form efficient. Due to the difference within the emerging world countries, a fundamental factor may play an important role in one emerging world country but may not be important for mergers in other emerging world countries. It may also be that because of the differences across the emerging world countries effect due to fundamental factors cancel out when we club the data from different countries together. Studying the cross-border mergers and acquisitions between two countries at a time especially when the merger and acquisition is between the developed world and the emerging world countries would hence provide more meaningful information. Also combining all targets in one group may cancel the effects of their different organizational form hence one should be cautious in deriving any inference from the papers studying all targets together and more meaningful information can be derived by splitting the targets into public and private.

In this paper, we examine the gains and losses to shareholders of both targets and acquirers, from mergers and acquisitions between the US and the developing country of India by separating the targets into their organizational forms (public, private and subsidiary firms). The overall purpose of our analysis is to bring new evidence to view on shareholder wealth from the cross-border (especially when the acquirer is from an emerging world country) merger and acquisition activity.

\section{Data, Variables and Methodology}

This study focuses on cross-border acquisitions between the US and India announced over the period January 1995 - August 2007. ${ }^{7}$ We extract our merger and acquisition sample from SDC's (Securities Data Corporation, a database

\footnotetext{
${ }^{7}$ We start the data in 1995 as there were very few mergers and acquisitions between Indian and US firms before that time.
} 
from Thomson Financial) Mergers and Acquisitions database during the sample period of January 1995 to August 2007. We use CRSP for daily returns and daily index returns for US firms and DataStream for the stock prices of Indian firms. We use the BSE200 (Bombay Stock Exchange) and the BSE500 from DataStream for the Indian market index. The BSE 500 is a more compensative index than BSE200, but it was first introduced on February 1, 1999. Hence, we use BSE200 as the Indian market index during 1995-1998 and BSE500 as the Indian market index after 1998.

Table 2: Number of acquiring and target firms in the sample

\begin{tabular}{|c|c|c|c|c|c|c|}
\hline \multirow{3}{*}{$\begin{array}{l}\text { Type of Merger and } \\
\text { Acquisition }\end{array}$} & \multicolumn{3}{|c|}{ US Target \& Indian Acquirer } & \multicolumn{3}{|c|}{ Indian Target \& US Acquirer } \\
\hline & & Data & Data & & Data & Data \\
\hline & $\begin{array}{l}\text { Total } \\
\text { M\&A }\end{array}$ & $\begin{array}{c}\text { available for } \\
\text { US Public } \\
\text { Firms }\end{array}$ & $\begin{array}{l}\text { available for } \\
\text { Indian Public } \\
\quad \text { Firms }\end{array}$ & $\begin{array}{l}\text { Total } \\
\text { M\&A }\end{array}$ & $\begin{array}{l}\text { available for } \\
\text { US Public } \\
\text { Firms }\end{array}$ & $\begin{array}{c}\text { available for } \\
\text { Indian Public } \\
\text { Firms }\end{array}$ \\
\hline Private Acquirer \& Private Target & 24 & & & 90 & & \\
\hline Private Acquirer \& Public Target & 4 & 4 & & 71 & & 34 \\
\hline Private Acquirer \& Subsidiary & 9 & & & 53 & & \\
\hline Public Acquirer \& Private Target & 110 & & 81 & 88 & 83 & \\
\hline Public Acquirer \& Public Target & 16 & 11 & 11 & 81 & 63 & 38 \\
\hline Public Acquirer \& Subsidiary & 45 & & 34 & 66 & 63 & \\
\hline Subsidiary \& Private Target & 11 & & & 55 & & \\
\hline Subsidiary \& Public target & 2 & 0 & & 61 & & 26 \\
\hline Subsidiary \& Subsidiary & 6 & & & 34 & & \\
\hline Others & 3 & 1 & 2 & 77 & 39 & \\
\hline Total & 230 & 16 & 128 & 676 & 248 & 98 \\
\hline
\end{tabular}

This table shows the number of acquiring and target firms in our initial sample and the final sample for the mergers and acquisitions between the US and the Indian firms.

The initial data set consists of 676 US acquisitions of Indian firms and 230 Indian acquisitions of US firms. This sample includes all the bidding and targets firms irrespective of whether or not the merger was successful. Firms without complete daily return or stock price information are excluded from the sample. As reported in Table 2, this reduces our initial sample to 248 US acquiring firms and 98 Indian target firms, and 16 US target firms and 128 Indian acquiring firms. In our sample all of the subsidiary targets are non-traded firms.

For the cross-sectional regression we collect the data on firm characteristics from SDC. There are several Indian firms with incomplete or missing data on SDC. We use DataStream to obtain the data on these firms. Excluding relative size data and the data on percentage owned after transaction, we have complete data on 99 Indian acquirers of US targets and 129 US acquirers of Indian targets. When we include the percentage owned after transaction our sample has 62 Indian acquirers of targets and 69 acquirers of Indian targets. When we include 
the relative size variable our sample size falls to 46 Indian acquirers of US targets and 41 US acquirers of Indian targets. We collect the data on the exchange rate from the website of the Federal Reserve Bank of St. Louis.

We compute the announcement date abnormal return on a three-day window of -1 day to 1 day after the announcement. We use the standard eventstudy methodology to analyse the impact of the acquisitions announcement on shareholders' wealth for both the acquiring and the target firms. We set the event date as the announcement date of the acquisition as reported in the SDC Platinum database.

The abnormal return for stock $\mathrm{j}$ on day $\mathrm{t}(\mathrm{)}$ ) is computed using the marketadjusted returns model:

$$
A R_{j t}=R_{j t}-E\left(R_{j t}\right)
$$

where is defined as the raw return of the common stock of the jth firm on day $t$, and is the expected return on stock $\mathrm{j}$. To calculate the expected return on stock $\mathrm{j}$, we use the market model:

$$
E\left(R_{j t}\right)=\alpha_{j}+\beta_{j}\left(R_{m t}\right)
$$

where is the daily market return using a value-weighted index, and for these firms are computed through a regression of the firm returns on the market returns during the time period of 120 days to 5 days before announcement. For US firms, the daily value-weighted return from CRSP is used as the proxy for the US market return; while for Indian firms, the BSE200 and BSE500 indices from DataStream are used as the proxy for the Indian market returns. ${ }^{8}$

The average abnormal return for day $\mathrm{t}$ is calculated as:

$$
A A R_{t}=\frac{\sum_{j=1}^{N} A R_{j t}}{N},
$$

where $\mathrm{N}$ is the number of firms in the sample. Over an interval of three days beginning with day -1 and ending with +1 , the cumulative average abnormal return is:

$$
C A A R_{-1,1}=\sum_{t=-1}^{1} A A R_{t}
$$

\footnotetext{
${ }^{8}$ BSE500 started in 1999 so we use BSE200 as a proxy for market index before 1999.
} 
To test the null hypothesis that cumulative average abnormal returns from -1 day to +1 day, is zero, we compute the t statistic (tstat) as:

$$
\text { tstat }=\frac{{C A A R_{-1,1}}}{\sqrt{\sum_{t=-1}^{1} s_{t}^{2} / n}}
$$

where is the average abnormal return on day $t$, is the sample variance of the average abnormal return for day $\mathrm{t}$, and $\mathrm{n}$ is the number of firms in the sample.

Our objective is to test if the cumulative average abnormal returns for acquirers or targets are significantly different from zero. We perform the following hypothesis test:

$$
H_{0}: \mu_{1}=0
$$

where is the cumulative average abnormal return. We use the t-test statistics of equation (5) to determine the statistical significance of the results.

\section{Results}

In this section, we analyse the shareholder wealth effects for both the acquiring and the target firms. We report the cumulative abnormal returns for acquirers and targets during the three-day event window of -1 day to 1 day after the announcement.

\subsection{US Acquirers and Indian Targets}

In Panel A of Table 3 we present the CAARs for US acquirers of Indian publiclytraded, privately-held and non-traded subsidiary firms. Though the sign on the cumulative abnormal returns around the announcement date is negative, the cumulative abnormal returns for acquiring US firms are not significant. When we split the sample ${ }^{9}$ into the US acquirers of publicly-traded, privately-held and subsidiary firm Indian target companies, we find the abnormal returns on the announcements of US acquisitions of publicly-traded and subsidiary firm targets are statistically insignificant. Shareholders of US firms who acquire privatelyheld Indian firms realize statistically significant abnormal returns of -1.1 per cent on the three day window $(-1$ to +1$)$.

\footnotetext{
${ }^{9}$ We do not study separately the acquirers of government firm targets and joint ventures. These targets are included in the overall sample. For this reason the sum of the acquirers of public targets (63 firms), private targets (83 firms) and subsidiary firm targets (63 firms) is less than the overall sample (248 firms).
} 
International Journal of Banking and Finance, Vol. 8, Iss. 1 [2011], Art. 3

Table 3: Abnormal returns of acquiring and Indian target firms

Panel A: American acquiring firms

\begin{tabular}{|c|c|c|c|c|}
\hline & $\begin{array}{l}\text { U.S. publicly- } \\
\text { traded firms } \\
\text { acquire Indian } \\
\text { targets ( } 248 \\
\text { firms) }\end{array}$ & $\begin{array}{l}\text { U.S. publicly- } \\
\text { traded firms } \\
\text { acquire Indian } \\
\text { publicly- } \\
\text { traded firms } \\
\text { (63 firms) }\end{array}$ & $\begin{array}{l}\text { U.S. publicly- } \\
\text { traded firms } \\
\text { acquire Indian } \\
\text { privately- } \\
\text { held firms } \\
\text { (83 firms) }\end{array}$ & $\begin{array}{l}\text { U.S. publicly- } \\
\text { traded firms } \\
\text { acquire } \\
\text { subsidiaries of } \\
\text { Indian firms } \\
\text { (63firms) }\end{array}$ \\
\hline CAAR $[-1,1]$ & -0.0041 & -0.0038 & $-0.0110^{*}$ & 0.0025 \\
\hline \multicolumn{5}{|c|}{ Panel B: Indian target firms } \\
\hline & $\begin{array}{l}\text { Indian targets } \\
\text { acquired by U.S } \\
\text { firms ( } 98 \text { firms) }\end{array}$ & $\begin{array}{c}\text { Indian targets } \\
\text { acquired by U.S. } \\
\text { publicly-traded } \\
\text { firms ( } 38 \text { firms) }\end{array}$ & $\begin{array}{l}\text { Indian targets } \\
\text { acquired by U.S. } \\
\text { privately-held } \\
\text { firms ( } 34 \text { firms) }\end{array}$ & $\begin{array}{l}\text { Indian targets } \\
\text { acquired by } \\
\text { subsidiaries of } \\
\text { U.S. firms ( } 26 \\
\text { firms) }\end{array}$ \\
\hline CAAR $[-1,1]$ & $0.0408^{* * * *}$ & $0.0449^{* * * *}$ & $0.0355^{* *}$ & $0.0407^{* *}$ \\
\hline
\end{tabular}

$* * *$ significant at the $1 \%$ level **significant at the $5 \%$ level *significant at the $10 \%$ level

Panel A presents the cumulative average abnormal returns for publiclytraded US firms that announced the acquisition of Indian target firms. The overall results in column 2 shows negative abnormal returns for the shareholders of the acquiring firms. When we separate them into different groups the results show losses for the acquirers of publicly- traded, privately-held and subsidiary firm targets. In Panel B we present the cumulative average abnormal returns around the announcement date for Indian target firms. Overall results in column 2 show that shareholders of target firms earn significant returns around the announcements of mergers and acquisitions. These results hold even when we separate these targets into being acquired by publicly-traded (public), privatelyheld (private) or subsidiary firms.

In Panel B of Table 3 we present the CAARs for publicly-traded Indian targets acquired by publicly-traded US firms, privately-held US firms and subsidiaries of US firms. We find a significant gain of 4.08 per cent for the set of Indian targets as a whole. When we look at the abnormal returns by the type of US acquirer - publicly-traded, privately-held or US subsidiary firms we find that the Indian targets realize significant gains of approximately 4 per cent across all types of acquirers for the three-day event window.

The above results indicate that the acquisition by any US firm (public, private or subsidiary firm) is beneficial to the shareholders of the Indian targets. The shareholders of US acquirers of Indian targets suffer losses around the announcement of mergers and acquisitions. 


\subsection{Indian Acquirers and US Targets}

In Panel A of Table 4 we show the CAARs for Indian acquirers of US targets. The acquisition announcement by Indian firms is associated with a 2.71 per cent stock price increases for the Indian acquiring firms. When we decompose the US targets into publicly-traded and privately-held firms, we find that the Indian firms do not realize statistically significant gains for acquisitions of publiclytraded US targets. Indian firms realize a statistically significant gain of 3.09 per cent for the acquisition of privately-held US firms and a gain of 2.26 per cent for their acquisition of US subsidiary firms.

In Panel B of Table 4 we report the CAARs of the US targets in the crossborder acquisitions. Our sample size is very small. For the sixteen publiclytraded US firms acquired by all types of Indian firms, the US targets experienced large positive abnormal returns but these were statistically insignificant. When we decompose the Indian acquirers into privately-held and publicly-traded companies, we find large cumulative abnormal returns for the US targets but these are not statistically significant.

These results indicate that Indian acquiring firms realize gains on the announcement of their acquisition of US firms although the gains are concentrated in acquisitions of privately-held or subsidiaries of US firms. No significant gains are earned in the acquisition of publicly-traded US companies.

Table 4: Abnormal returns for Indian acquiring and target firms

Panel A: American acquiring firms

\begin{tabular}{ccccc}
\hline & $\begin{array}{c}\text { Indian publicly- } \\
\text { traded firms } \\
\text { acquire U.S. } \\
\text { targets } \\
\text { (128 firms) }\end{array}$ & $\begin{array}{c}\text { Indian publicly- } \\
\text { traded firms } \\
\text { acquire U.S. } \\
\text { publicly-traded } \\
\text { firms (11 firms) }\end{array}$ & $\begin{array}{c}\text { Indian publicly- } \\
\text { traded firms } \\
\text { acquire U.S. } \\
\text { privately-held } \\
\text { firms (81 firms) }\end{array}$ & $\begin{array}{c}\text { Indian publicly- } \\
\text { traded firms } \\
\text { acquire } \\
\text { subsidiaries of } \\
\begin{array}{c}\text { U.S. firms (34 } \\
\text { firms) }\end{array}\end{array}$ \\
\hline CAAR [-1, 1] & $0.0271 * * *$ & 0.0054 & $0.0309 * * *$ & $0.0226^{* *}$
\end{tabular}

Panel B: US targets

\begin{tabular}{ccc}
$\begin{array}{c}\text { U.S. targets } \\
\text { acquired by } \\
\begin{array}{c}\text { Indian firms (16 } \\
\text { firms })\end{array}\end{array}$ & $\begin{array}{c}\text { U.S. targets } \\
\text { acquired by } \\
\text { Indian publicly- } \\
\text { traded firms } \\
\text { (11 firms) }\end{array}$ & $\begin{array}{c}\text { U.S. targets } \\
\text { acquired } \\
\text { by Indian } \\
\text { privately-held } \\
\text { firms (4 firms) }\end{array}$ \\
\hline 0.1812 & 0.1850 & 0.0389 \\
\hline
\end{tabular}

$* * *$ significant at the $1 \%$ level $* *$ significant at the $5 \%$ level *significant at the $10 \%$ level 
Panel A presents the cumulative average abnormal returns for publiclytraded Indian firms which announced the acquisition of U.S. targets. The overall results in column 2 show positive abnormal returns for the shareholders of the acquiring firms. When we separate them into different groups, publiclytraded (public), privately-held (private) and subsidiary firms the results indicate substantial gains for the acquirers of the privately-held targets and subsidiary firm targets.

Panel B presents the cumulative average abnormal returns around the announcement date for the US target firms. The shareholders of the target firms gain from the announcement of mergers and acquisitions but this gain is statistically insignificant.

\section{Explanations of the Empirical Results}

\subsection{Public, Private and Subsidiary firm Acquirers and Public Targets}

Obviously, the shareholders of public targets will agree to sell their perpetual dividend stream and future capital gains when they believe that the future prospects of the company's growth are bleaker than the buyer's beliefs. They would also agree to sell if they get a very lucrative offer from a buyer and there are possibilities for further negotiations of the prize. In either of these cases the merger is good news for the shareholders and should result in positive abnormal returns.

Bargeron, Schlingemann, Stulz and Zutter (2008) find that the premium paid for acquisitions of public targets is significantly lower when the acquirer is a private firm instead of a public firm. They propose a managerial discretion theory of takeovers where managers may gain from the acquisitions that do not benefit shareholders.

Due to the private benefits of acquisitions for managers, they pay more for target firms than shareholders would. Bargeron et al. (2008) provide evidence consistent with the managerial discretion theory of takeovers by showing that the difference in target shareholder gains between acquisitions by privately-held and by publicly-traded firms fall as the proportion of managerial ownership of the publicly-traded bidder increases.

Our results are consistent with Bargeron et al. (2007) in that we find the abnormal returns for the targets of publicly-traded acquirers to be consistently higher than the abnormal returns of targets of privately-held acquirers; (a) the abnormal returns for the Indian targets of publicly-traded US acquirers are 4.49 per cent (significant at 1\% level) and the abnormal returns for the Indian targets of privately-held US acquirers are 3.55 per cent (significant at 5\% level), (b) the abnormal returns of the US targets of publicly-traded Indian acquirers are 18.50 per cent and the abnormal returns of the US targets of privately-held Indian acquirers are 3.89 per cent, though both of these are statistically insignificant. 


\subsection{Public-Traded Acquirer and Publicly Traded, Private and Subsidiary firm Targets}

In section 4 we found that shareholders of US acquirers of Indian targets suffered losses on and around the announcement of mergers and acquisitions of Indian companies. However, shareholders of Indian firms gained on the announcement of their acquisition of privately-held US firms and subsidiaries of US firms. We investigate if this opposite reaction is due to firm specific characteristics by regressing the three-day cumulative abnormal return around announcement (-1 day to +1 day after announcement) on the following firm specific characteristics ${ }^{10}$ :

- $\quad$ Relative size $=$ Value of deal/market value of acquirer ${ }^{11}$ Moeller and Stulz (2004) find that for domestic acquisitions large firms loose when they acquire small firms whereas small firms gain when they acquire large firms. Moeller and Stulz (2004) find that small acquirers acquiring large firms have 2 per cent higher announcement returns.

- $\quad$ Acquirer size = Market value of acquirer. Mitchell and Stafford (2000) find that announcement returns are positively related to the size of the acquirer for domestic acquisitions.

- $\quad$ High-Tech = "1" if both target and acquirer are defined as high tech by the SDC Thomson data source and "0" otherwise. Conn et al. (2005) find that firms (both acquiring and target) in the same high-tech industry have a positive influence on the returns of the acquirer.

- $\quad$ Related $=$ " 1 " if target and acquirer have the same four-digit SIC code and "0" otherwise. This variable measures if the merger is within the industry or if the firms are diversifying. Megginson, Morgan and Nail (2004) find that for domestic acquisitions gains are higher in related acquisitions.

- Value $=$ " 1 " if acquirer's market to book value of equity is in quintile one and "0" otherwise.

- $\quad$ Glamour = " 1 " if acquirer's market to book value of equity is in quintile five and "0" otherwise. These definitions of value and glamour variables are from Conn et al. (2005).

- $\quad \mathrm{TQ}=$ Tobin's q of the acquirer. We estimate Tobin's q as the market value of firm divided by the book value.

- Downer= Dummy equals "1" if the majority stake is acquired (greater than 50\%) and "0" otherwise. Chari et al. (2010) find that acquirers from the developed world gain when they announce acquisition of majority stake in firms from the emerging world.

- $\quad$ DAQC $=$ " 1 " if the acquirer is from $\mathrm{A}$ and " 0 " if the acquirer is from India.

\footnotetext{
${ }^{10}$ We define these characteristics similar to Conn et al. (2005). Due to the limitation of data available on the SDC Thompson data source, we are unable to study all the firm characteristics discussed in Conn et al. (2005).

${ }^{11}$ Where the data on value of deal is unavailable we use the definition of relative size given by Cakici, Hassel and Tandon (1996) who define relative size as the value of outstanding equity of targets/equity of bidder.
} 
We provide the summary statistics by cross-border relationship for the above variables in Table 5. We find that the Indian and the US acquirers of private targets have similar high-tech status levels. The Indian acquirers of publiclytraded US targets and US subsidiary firm targets are more often classified as high-tech status as compared to US acquirers of publicly-traded Indian firms and Indian subsidiary firm targets. Irrespective of the target firm status, Indian acquirers appear to engage in company diversification more than US acquirers. The relative size of the targets is substantially smaller for US acquisitions. The market value of Indian acquirers of US targets is also significantly lower than the market value of US acquirers of Indian targets. Though the average percentage owned after the transaction by Indian acquiring firms is higher than the percentage owned after the transaction by acquirers, both Indian and acquirers, acquire majority stakes in the target firms. For both the US and Indian acquirers, the average stake acquired in the private and subsidiary firm targets is higher than the average stake acquired in publicly-traded targets.

Table 5: Summary statistik of the US and Indian acquiring and target firms

\begin{tabular}{lccc}
\hline Panel A: Indian Acquirer of US Target & & & \\
\hline & $\begin{array}{c}\text { Publicly- } \\
\text { traded target }\end{array}$ & $\begin{array}{c}\text { Privately } \\
\text { held target }\end{array}$ & $\begin{array}{c}\text { Subsidiary } \\
\text { targe }\end{array}$ \\
\hline High tech & 0.583 & 0.532 & 0.500 \\
Related & 0.250 & 0.274 & 0.308 \\
Market value of acquirer (\$Million) & 2238 & 835 & 1185 \\
Market value/ book value of equity & 10.739 & 4.464 & 4.980 \\
$\begin{array}{l}\text { Acquirers book value of common equity } \\
\text { (\$Million) }\end{array}$ & 171 & 210 & 260 \\
$\begin{array}{l}\text { Acquirer total assets (\$Million) } \\
\text { \# of firms above data is available for }\end{array}$ & 11 & 377 & 508 \\
$\begin{array}{l}\text { average \% owned after transaction } \\
\text { (OAT) }\end{array}$ & 75.75 & 88.82 & 96.71 \\
$\begin{array}{l}\text { OAT data available for (\# of Firms) } \\
\text { Firms) }\end{array}$ & 4 & 110 & 10 \\
$\begin{array}{l}\text { Relative size } \\
\text { Relative size data available for (\# of }\end{array}$ & 9.362 & 0.110 & 0.481 \\
\hline
\end{tabular}




\begin{tabular}{lccc}
\hline Panel B: US Acquirer of Indian Target & & & \\
\hline & $\begin{array}{c}\text { Publicly- } \\
\text { traded target }\end{array}$ & $\begin{array}{c}\text { Privately } \\
\text { held target }\end{array}$ & $\begin{array}{c}\text { Subsidiary } \\
\text { targe }\end{array}$ \\
\hline High tech & 0.264 & 0.558 & 0.273 \\
Related & 0.415 & 0.349 & 0.394 \\
Market value of acquirer (\$Million) & 52523 & 6143 & 32489 \\
Market value/ book value of equity & 7.349 & 7.214 & 4.465 \\
$\begin{array}{l}\text { Acquirers book value of common equity } \\
\text { (\$Million) }\end{array}$ & 14066 & 2093 & 6965 \\
Acquirer total assets (\$Million) & 135979 & 5381 & 34739 \\
\# of firms above data is available for & 53 & 43 & 33 \\
$\begin{array}{l}\text { average \% Owned After Transaction } \\
\text { (OAT) }\end{array}$ & 50.3 & 84.24 & $79-87$ \\
$\begin{array}{l}\text { OAT data available for (\# of Firms) } \\
\text { Relative size }\end{array}$ & 21 & 28 & 20 \\
\hline $\begin{array}{l}\text { Total number of firms } \\
\text { Rize data available for (\# of }\end{array}$ & 19 & 0.016 & 606 \\
\hline
\end{tabular}

In Panel A we present the summary statistics for the Indian acquirers of US targets and in Panel B we present the summary statistics for the US acquirers of Indian targets. A comparison of Panel A and Panel B shows that the relative size of US targets is substantially higher than the relative size of Indian targets and the US acquirers have higher market value than the Indian acquirers. The Indian acquirers of the US targets diversify their business more than the US acquirers of the Indian targets.

We regress the CAAR for the acquirers of public, private and subsidiary targets on these variables to investigate whether there are abnormal return differences to the acquirer's home country after controlling for firm characteristics. The data for relative size and percentage owned after transaction is available for fewer firms hence for each of the target types we first run the regression without the variables, 'relative size' and 'Downer' as the lack of data on these variables substantially reduces the sample size. We use the following three models to test if the CAARs are country dependent: 
International Journal of Banking and Finance, Vol. 8, Iss. 1 [2011], Art. 3

Mode

$$
\begin{aligned}
& \text { CAAR }_{i}=\alpha+\beta_{1} \text { HighTech }_{i}+\beta_{2} \text { Related }_{i}+\beta_{3} \text { LMV }_{i}+ \\
& \beta_{4} \text { TQ }_{i}+\beta_{5} \text { Value }_{i}+\beta_{6} \text { Glamour }_{i}+\beta_{7} \text { DAQC }_{i}+\beta_{8} \text { EXC }_{i}+\varepsilon_{i}
\end{aligned}
$$

Model II:

$$
\begin{aligned}
& \text { CAAR }_{i}=\alpha+\beta_{1} \text { HighTech }_{i}+\beta_{2} \text { Related }_{i}+\beta_{3} \text { LMV }_{i}+ \\
& \beta_{4} \text { TQ }_{i}+\beta_{5} \text { Value }_{i}+\beta_{6} \text { Glamour }_{i}+\beta_{7} \text { DAQC }_{i}+\beta_{8} \text { EXC }_{i}+ \\
& \beta_{9} \text { Downer }_{i}+\varepsilon_{i}
\end{aligned}
$$

Model III:

$$
\begin{aligned}
& \text { CAAR }_{i}=\alpha+\beta_{1} \text { HighTech }_{i}+\beta_{2} \text { Related }_{i}+\beta_{3} \text { LMV }_{i}+\beta_{4} \text { TQ }_{i}+ \\
& \beta_{5} \text { Value }_{i}+\beta_{6} \text { Glamour }_{i}+\beta_{7} \text { DAQC }_{i}+\beta_{8} \text { EXC }_{i}+\beta_{9} \text { RelativeSize }_{i}+\varepsilon_{i}
\end{aligned}
$$

where LMV is the log of market value of the acquirer. EXC in the above equation is the exchange rate variable ${ }^{12}$ which measures the effect of changes in the exchange rate on mergers and acquisitions. We follow Cakici et al. (1996) who estimate the effects of exchange rate variable on bidding shareholders' wealth as a result of foreign acquisitions of the US firms, and compare these to a control sample of foreign acquisitions by US firms.

We pool the country data and run the above regression models for the acquirers of publicly-traded, privately-held and subsidiary targets separately. The results are reported in Table 6. For the acquirers of publicly-traded and subsidiary targets we find an insignificant DAQC variable suggesting that there is no country difference in the abnormal returns of the Indian and the US acquirers of the publicly-traded and subsidiary targets.

In the following table we present the regression on the CAAR ( -1 day to +1 day after the announcement) as a dependent variable for the acquirers of public, private and subsidiary targets. After controlling for firm characteristics we find that the dummy variable for country (DAQC $=1$ for US acquirers and $\mathrm{DAQC}=0$ for Indian acquirers) is negative and significant for the acquirers of private targets suggesting a lower abnormal return for the US acquirers as compared to the Indian acquirers of private targets.

The coefficient for the sample of publicly-traded acquirers of privatelyheld targets is negative and significant suggesting a lower CAAR for the US acquirers of privately-held Indian targets as compared to the Indian acquirers of privately-held US targets.

\footnotetext{
${ }^{12}$ We compute the exchange rate variable using the method adopted by Cakici et al. (1996). We take the Indian currency's average exchange rate (per dollar) for the sample period 1995-2007 and subtract the Indian currency's exchange rate for the year of acquisition. Then we divide this difference by the average exchange rate.
} 
Table 6: Regression results of cross-border mergers and acquisitions

\begin{tabular}{lccccccccc}
\hline & \multicolumn{3}{c}{ Public Target } & \multicolumn{3}{c}{ Private Target } & \multicolumn{3}{c}{ Subidiary Target } \\
\hline Variable & I & II & II & I & II & II & I & II & II \\
\hline Intercept & -0.030 & -0.017 & -0.020 & $0.037 *$ & 0.041 & 0.067 & 0.017 & 0.064 & -0.017 \\
High tech & 0.009 & 0.026 & 0.020 & 0.009 & 0.002 & -0.001 & -0.002 & 0.001 & $0.063^{* * *}$ \\
Related & -0.001 & -0.013 & $-0.034^{*}$ & 0.003 & 0.014 & 0.005 & -0.003 & 0.008 & -0.008 \\
LMV & 0.005 & 0.007 & 0.004 & -0.001 & -0.002 & -0.002 & 0.002 & -0.001 & 0.004 \\
TQ & 0.001 & -0.005 & 0.000 & -0.001 & 0.001 & -0.002 & 0.000 & 0.000 & -0.005 \\
Value & 0.022 & -0.008 & $0.071^{* *}$ & -0.001 & 0.000 & -0.006 & 0.021 & 0.019 & 0.018 \\
Glamour & -0.004 & -0.010 & 0.014 & -0.006 & $-0.034 *$ & 0.019 & -0.036 & -0.011 & -0.003 \\
EXC & 0.045 & 0.088 & 0.038 & 0.058 & -0.121 & 0.181 & 0.070 & -0.011 & 0.197 \\
DAQC & -0.019 & -0.006 & -0.014 & $-0.044 * * *-0.053 * * *$ & $-0.044 *$ & -0.020 & -0.024 & -0.014 \\
Relative size & & & $-0.105 *$ & & & -0.024 & & & $0.028 * * *$ \\
\hline \# of firms & 65 & 25 & 28 & 104 & 69 & 38 & 59 & 37 & 20 \\
\hline Rsquare & 0.095 & 0.266 & 0.401 & 0.196 & 0.197 & 0.197 & 0.146 & 0.232 & 0.786 \\
\hline
\end{tabular}

\section{Conclusion}

Prior empirical research on mergers and acquisitions is predominantly related to the developed markets of the US and Europe. There is limited work on mergers and acquisitions when targets from the developed world are acquired by companies from the developing world. In the cross-border mergers and acquisitions between developed and developing world firms, researchers have studied the effect of the announcement of mergers and acquisitions on the acquirer firms only. None of the studies to date have investigated the effect of announcement of mergers and acquisitions on the target firms. In this paper we studied the cross-border mergers and acquisitions between the US and India for both acquirers as well as target firms.

We used data on mergers and acquisitions from January 1995 to August 2007 and found that the mergers and acquisitions with US acquirers and Indian targets resulted in significant losses for the acquirers and significant gains for the targets. Mergers and acquisitions between Indian acquirers and US targets resulted in significant gains for the acquirers and insignificant gains for the targets.

We further examined the abnormal returns by decomposing the sample of firms into publicly-traded, privately-held and non-traded subsidiary firms. We found that the US acquirers of publicly-traded Indian firms realize insignificant losses while publicly-traded Indian targets acquired by US firms earned significant returns on the announcement of a merger or acquisition. Indian acquirers of publicly-traded US firms earned insignificant gains/losses and US targets of publicly-traded Indian acquirers earned insignificant positive abnormal returns on the announcement of mergers and acquisitions. These results are similar to the results we found in the existing literature. 
In the cross-border acquisition of private targets, publicly-traded US acquirers suffered losses whereas publicly-traded Indian acquirers realized gains. The Indian acquirers of US subsidiary firm targets realized significant gains while the US acquirers of Indian subsidiary firm targets realized insignificant gains/losses. We investigated these cross-border merger and acquisition results to determine if the results were due to firm characteristics or country dependent by regressing the cumulative abnormal returns on the firm characteristics and a dummy variable for the country of the acquirer.

For the private targets, we found the country dummy variable to be significant after controlling for firm characteristics indicating a lower abnormal return for US acquirers of privately-held Indian firms as compared to the Indian acquirers of privately-held US firms. The dummy variable is not significant for the acquirers of publicly-traded firms and for subsidiary firm targets indicating that firm characteristics and not the country environments govern the returns on these mergers and acquisitions.

Author information: Professors Gordon Karels, Edward Lawrence and Jin $\mathrm{Yu}$ are staff member of the finance faculty respectively at the University of Nebraska-Lincoln, Florida International University and St. Cloud State University, all in the USA. They may be contacted at: gkarels@unl.edu; edward. lawrence@fiu.edu; iyu@stcloundstate.edu.

\section{References}

Aybar B. \& Ficici A. (2009). Cross-border acquisitions and firm value: An analysis of emerging-market multinationals. Journal of International Business Studies, 40, 1317-1338.

Baldwin J. R. \& Caves, R. E. (1991). Foreign multinational enterprises and merger activity in Canada. In L. Waverman (Ed.). Corporate globalization through mergers and acquisitions. Calgary: University of Calgary Press, 89-122.

Bargeron, L., Schlingemann, F. P., Stulz, R. M. \& Zutter, C. J. (2008). Why do private acquirers pay so little compared to public acquirers? Journal of Financial Economics, 83, 375-390.

Cakici N., Hassel, C. \& Tandon, K. (1996). Foreign acquisitions in the United States: Effect on shareholder wealth of foreign acquiring firms. Journal of Banking and Finance, 20, 307-329.

Caves, R. E. (1971). International corporations: The industrial economics of foreign investment. Economica, 38, 1-27.

Caves, R. E. (1998). Research on international business: Problems and prospects. Journal of International Business Studies, 29, 5-19.

Chari, A., Ouimet, P. \& Tesar, L. (2010). The value of control in emerging markets. Review of Financial Studies, Forthcoming.

Conn, R. L., Cosh, A., Guest, P. M. \& Hughes, A. (2005). Impact on UK acquirers of domestic, cross-border, public and private acquisitions. Journal of Business, Finance and Accounting, 32, 815-870. 
Denis, D. J., Denis, D. K. \& Yost, K. (2002). Global diversification, industrial diversification and firm value. The Journal of Finance, 57, 1951-1979.

Doukas, J., (1995). Overinvestment, Tobin's q and gains from foreign acquisitions. Journal of Banking and Finance, 19, 1285-1303.

Doukas, J. \& Travlos, N. G. (1988). The effect of corporate multinationalism on shareholders' wealth: Evidence from international acquisitions. Journal of Finance, 43, 1161-1175.

Eckbo, B. E. \& Thorburn, K. S. (2000). Gains to bidder firms revisited: Domestic and foreign acquisitions in the US. Journal of Financial and Quantitative Analysis, 35, 1-24.

Eun, C. S., Kolodny, R. \& Scherga, C. (1996). Cross-border acquisitions and shareholder wealth: Tests of the synergy and internalization hypothesis. Journal of Banking and Finance, 20, 1559-1582.

Francis, B. B., Hasan, I. \& Sun, X. (2008). Financial market integration and the value of global diversification: Evidence for acquirers in cross-border mergers and acquisitions. Journal of Banking \& Finance, 32, 1522-1540.

Gubbi, S. R., Aulakh, P. S., Ray, S., Sarkar, M. B. \& Chittor, R. (2010). Do international acquisitions by emerging economy forms create shareholder value? The case of Indian firms. forthcoming in the International Journal of Business Studies.

Hitt, M. A., Hoskisson, R. E. \& Ireland, D.R. (2001). A mid-range theory of the interactive effects of international and product diversification on innovation and performance. Journal of Management, 20, 297-326.

Hitt, M. A., Ireland, R. D., Camp, S. M. \& Sexton, D. L. (2001). Strategic entrepreneurship: Entrepreneurial strategies for wealth creation. Strategic Management Journal, 22, 479-491.

Kissin, W. D. \& Herrera, J. (1990). International mergers and acquisitions. Journal of Business Strategy, 11, 51-54.

Kiymaz, H. (2004). Cross-border acquisitions of financial institutions: impact of macroeconomic factors. Journal of Banking and Finance, 28, 1413-1439.

Kogut, B. (1983). Managing political risk assessment. Sloan Management Review, 24, 71-73.

La Porta, R., Lopez-de-Silanes, F., Shleifer, A. \& Vishny, R. (1998). Law and finance. Journal of Political Economy, 106, 1113-1155.

La Porta, R., Lopez-de-Silanes, F., Shleifer, A. \& Vishny, R. (1999). Corporate ownership around the world. Journal of Finance, 54, 471-517.

La Porta, R., Lopez-de-Silanes, F., Shleifer, A. \& Vishny, R. (2000). Investor protection and corporate governance. Journal of Financial Economics, $58,3-27$.

Markides, C. C. \& Ittner, C. D. (1994). Shareholder benefits from corporate international diversification: Evidence from U.S. international acquisitions. Journal of International Business Studies, 25, 343-366.

Markides, C. \& Oyon , D. (1998). International acquisitions: Do they create value for shareholders? European Management Journal ,16, 125-135. 
International Journal of Banking and Finance, Vol. 8, Iss. 1 [2011], Art. 3

Megginson, W. L., Morgan, A. \& Nail, L. (2004). The determinants of positive long-term performance in strategic mergers: Corporate focus and cash. Journal of Banking and Finance, 28, 523-52.

Mitchell, M. L. \& Stafford, E. (2000). Managerial decisions and long-term stock price performance. Journal of Business, 73, 287-329.

Moeller, S. B. \& Stulz, R. M. (2004). Firm size and the gains from acquisitions. Journal of Financial Economics, 73, 201-228.

Moeller, S. B. \& Schlingemann, F. P. (2005). Global diversification and bidder gains: A comparison between cross-border and domestic acquisitions. Journal of Banking and Finance, 29, 533-564.

Morck, R. A. \& Yeung, B. (1991). Why investors value multinationality. Journal of Business, 64, 165-187.

Morck, R. A. \& Yeung, B. (1992). Internalization: An event-study test. Journal of International Economics, 33, 41-56.

Mulherin, J. H. \& Audra L. B. (2000). Comparing acquisitions and divestitures. Journal of Corporate Finance, 6, 117-139.

Rossi, S. \& Volpin P. F. (2004). Cross-country determinants of mergers and acquisitions. Journal of Financial Economics, 74, 277-304.

Seth, A., Song, K. P. \& Pettit, R. (2002). Value creation and destruction in crossborder acquisitions: An empirical analysis of foreign acquisitions of U.S. firms. Strategic Management Journal, 23, 921-940.

Williamson, O. E. (1979). Transaction-cost economics: The governance of contractual relations. Journal of Law and Economics, 22, 233-261. 